\title{
Test of the Effectiveness of Anti-Dyslipedemia Extract Ethanol Mangosteen Peel (Garcinia Mangostana L.) in Male Mice Fed a High-Fat Diet
}

\author{
Zhang Yu ${ }^{1}$, Florenly $^{2}$, Liena $^{3}$, Fioni $^{4}$ \\ 1,2,3,4 Master of Clinical Medicine, Faculty of Medicine, Universitas Prima Indonesia \\ Email: liena@unprimdn.ac.id
}

\begin{abstract}
:
Dyslipidemia is a major risk factor for atheroscler heart disease, stroke, and is often defined as abnormalities or disruption of lipid metabolism. Garcinia mangostana L. is famous for its antiinflammatory properties and is used in the treatment of skin infections and wounds. The main phytochemicals present in this species are anisoprenylated xanthone, many reports of biological effects, such as antioxidant, pro-apoptosis, anti-proliferative, anti-nosiseptif, anti-inflammatory, neuroprotective, hypoglycemic, and anti-obesity. This study aims to find out the effectiveness of mangosteen peel ethanol extract as an anti-dyslipidemia in male wistar rats given a high-fat diet. This type of research is experimental with a Pre-test approach and Post-test group only control design. The samples used were mangosteen peel ethanol extract and male wistar rats, with the size of the sample calculated with Federer's formula. Analyze data with the One-Way Anova Test if the data is normally distributed with advanced tests in the form of Post Hoc Tukey HSD tests to see real differences between treatments. The results of the total cholesterol study in the entire treatment group of mice showed a significant difference in P values $<0.05$. Triglyceride levels in the entire treatment group also showed significant differences, this can be seen from the value of $P<0.05$ (Value $P=0.029$ ). LDL levels also showed significant differences across the treatment group, which can be seen from the $P$ value of $<0.05$. HDL levels make a significant difference in the value of $P<0.05$ (Value $P=0.029$ ). SGOT and SGPT levels in the entire group of rat treatment showed significant differences, this was seen from the value of $P<0.05$. The conclusion that mangosteen peel ethanol extract significantly lowered total cholesterol, triglyceride levels, LDL levels, SGOT levels compared to the control group. Mangosteen peel ethanol extract can significantly increase HDL levels compared to the control group.
\end{abstract}

Keywords:

dyslipedemia; garcinia mangostana; fat

\section{Introduction}

Dyslipidemia is a major risk factor for coroner's heart disease, and is often defined as abnormalities or disruption of lipid metabolism due to the interaction of genetic and environmental factors (Erwinanto et al., 2013; Arsana et al., 2015). Based on data from the World Health Organization (WHO) in 2008, estimates that the prevalence of dyslipdemia in various regions varies by 30.3\% in Southeast Asia, 47.7\% in the Americas (Lin et al., 2018); (Go et al., 2014). High cholesterol turns out to be an etiology that very often causes atherosclerosis, stroke, and cardiovasculer disease (Taqwin, 2014). As many as $35.9 \%$ of Indonesians aged $\geq 15$ years with abnormal cholesterol levels (based on NCEP ATP III, with cholesterol levels $\geq 200 \mathrm{mg} / \mathrm{dl}$ ) where women are more than men and urban more than in rural areas (Badan Penelitian Dan Pengembangan Kesehatan Kementerian Kesehatan RI, 2013) 


\section{Britain International of Exact Sciences (BIoEx) Journal \\ ISSN: 2686-1208 (Online), 2686-1216 (Print) \\ Vol. 4, No. 1, January 2022, Page: 1-12 \\ Email: bioexjournal@gmail.com}

In the management of dyslipidemia, there are several anti-dyslipidemia drugs on the market including statins, fibrats, niacin, ezetimibe, and bile acid binding resins (Purva, Sharma and Khan, 2020). However, the use of these drugs shows some adverse side effects of health (Saragih, 2020). So that alternative treatments such as herbal medicines are needed, which certainly have lower side effects (Anneke and Sulistiyaningsih, 2018). Indonesia is available about 30,000 species of plants, including medicinal plants that amount to 2,500 species of plants (Dalimartha and Adrian, 2013). One of the natural ingredients that have the potential to be an alternative treatment is the skin of mangosteen fruit. So far the use of mangosteen skin is only for tanning skin, traditional medicine, and materials that make antiques and textile dyes. The utilization of mangosteen peel for treatment in Indonesia is still not much, especially as Anti-Dyslipidemia. Therefore, this study aims to find out the effectiveness of mangosteen peel ethanol extract as an anti-dyslipidemia in male Wistar rats given a high-fat diet.

\section{Review of Literature}

Garcinia mangostana L. (mangosteen, Clusiaceae) has long been used as a medicinal plant. Traditionally mangosteen is famous for its anti-inflammatory properties and is used in the treatment of skin infections and wounds (Jang et al., 2008). The main phytochemicals present in this species are xanthone isisoprenylated, a class of secondary metabolites with many reports of biological effects, such as antioxidants, pro-apoptosis, anti-proliferative, antinosiseptif, anti-inflammatory (Parmita, in and Armyanti, 2017), neuroprotektif, hipoglikemik, dan anti-obesitas. Currently mangosteen peel is widely developed as a new drug to treat chronic and degenerative diseases (Ovalle-Magallanes, Eugenio-Pérez and PedrazaChaverri, 2017). According to (Putra SR, 2012), Mangosteen peel contains organic compounds namely xanthones. Pasaribu, dkk. (2012), Ethanol extract 96\% mangosteen peel contains chemical compounds alkaloida, flavonoids, glycosides, saponins, tannins and steroids / triterpenoids (Bahri, Pasaribu and Sitorus, 2012). The content of flavonoids and alkaloids mangosteen skin can have an effect as an analgesic. In addition, flavonoids are able to inhibit prostaglandins so that they have antipyretic effects (Puspitaningrum, Kusmita and Setyani, 2014). Dyslipidemia is defined as a lipid metabolic disorder characterized by an increase or decrease in lipid fraction in plasma.

\section{Research Methods}

This type of research is experimental with a Pre-test approach and Post-test group only control design. The samples used are mangosteen peel ethanol extract and male wistar rats, with the size of the sample calculated with Federer's formula, so it takes at least 4 male wistar rats (Rattus norvegicus) in each treatment group.

Table 1. Aspects of Measurement of Research Variables

\begin{tabular}{|c|c|c|c|c|c|}
\hline No & Variabel & Cara Ukur & Alat Ukur & Hasil Ukur & Skala Ukur \\
\hline 1. & $\begin{array}{l}\text { Dosage of } \\
\text { mangosteen peel } \\
\text { ethanol extract }\end{array}$ & $\begin{array}{l}\text { Measured the weight } \\
\text { and volume of extracts } \\
\text { and vehiculum extracts } \\
\text { with analytical scales } \\
\text { and pumpkin } \\
\text { measures. }\end{array}$ & $\begin{array}{l}\text { Analytical scales } \\
\text { and measuring } \\
\text { pumpkins. }\end{array}$ & $\begin{array}{ll}\text { 1. } & \text { Control } \\
\text { 2. } & \text { Standard }\end{array}$ & Ordinal \\
\hline 2. & Profile Lipid & $\begin{array}{l}\text { Lipoprotein analysis } \\
\text { can measure blood } \\
\text { levels of the amount }\end{array}$ & Spektroskopik & Deep mg/dl & Ratio \\
\hline
\end{tabular}




\begin{tabular}{|c|c|c|c|c|c|}
\hline & & $\begin{array}{l}\text { of cholesterol, } \\
\text { cholesterol, } \\
\text { cholesterol, } \\
\text { triglycerides. }\end{array}$ & & & \\
\hline 3. & $\begin{array}{l}\text { Up to Kolestrol } \\
\text { Total }\end{array}$ & $\begin{array}{l}\text { Combined amount of } \\
\text { LDL cholesterol, } \\
\text { HDL cholesterol, and } \\
\text { triglycerides in each } \\
\text { deciliter of blood. }\end{array}$ & Autocheck ${ }^{\circledR}$ & Deep mg/dl & Ratio \\
\hline 4. & Weight & Weighed using scales. & Analytical scales & Deep gram & Ratio \\
\hline
\end{tabular}

Sample data such as gender, age, intrapulmonary symptoms, extrapulmonary symptoms, comorbidities, SGOT and SGPT enzyme test results when the patient was admitted to the ICU or from the first examination data when the patient was admitted to the ICU Infection Center, prognosis. The normality test used the Kolmogorov-Smirnov test, then the correlative test used the Pearson test, the Kruskal-Wallis test to assess each group of elevated transaminase enzymes on the prognosis of COVID-19 patients and the Chi-Square test to assess the correlation of intrapulmonary symptoms, extrapulmonary symptoms and comorbid diseases to the increase transaminases enzymes. Statistical analysis using SPSS 22.0 for windows program.

\subsection{Tool}

Surgical tools, laboratory glass tools, aluminum foil, blender (Miyako), porcelain cups, deikators, incubators, glass objects, cover glass, porcelain crusts, dryer cabinets, microtubes, light microscopes, analytical balance sheets (Vibra AJ), oral sonde, electric oven (Stork), water handler (Yenaco), tube clamps, test tube racks, rotary evaporators, centriofigators, a set of water content determination tools, UV spectrophotometers (Microlet 3000), injection spuits, tanurs (Nabertherm), test tube, animal scales (Presica).

\subsection{Material}

The ingredients used in the study were mangosteen fruit, methanol, Aquades, NaCMC (Sodium-Carboxyl methylcellulose), simvastatin, chaff, rat food pellets, phytochemical screening reagents, and ketamine.

\subsection{Research Procedure}

Samples of mangosteen fruit used in this study were obtained from one of the traditional markets in Medan City. Then the sample of mangosteen fruit was later identified at the Herbarium Medanense FMIPA USU. Mangosteen peel proceeds to the manufacture of simplisia (Kosasih et al., 2019), ethanol extract (Depkes RI, 1979), phytochemical screening (Widowati et al., 2016, 2017, 2018).

\subsection{Anti-Dyslipidemia}

Manufacture of $\mathrm{Na}$ CMC Suspension $0.5 \%$, as much as 0.5 grams of $\mathrm{Na}$ CMC sprinkled into lumpang containing hot distilled water as much as $10 \mathrm{~mL}$ (Mutia and Chiuman, 2019). Making hyperchoestrolemia feed suspension, the suspension is made by mixing 300 grams of animal fat into $100 \mathrm{ml}$ of aquadest and 200 grams of poultry egg yolk into $1 \mathrm{ml}$ of $\mathrm{Na}-\mathrm{CMC}$ 0.5\% (Harsa, 2014). Suspension of Mangosteen Peel Extract, As much as 1.2grams of mangosteen peel extract is put into lumpang and added suspension $\mathrm{Na}$ CMC $0.5 \%$ little by little while being eroded until homogeneous and then put into pumpkin of course $10 \mathrm{~mL}$. The volume is sufficient with a $0.5 \% \mathrm{Na}$ CMC suspension up to the mark line (Mutia and Chiuman, 2019). Simvastatin suspension, as much as $10 \mathrm{mg}$ of simvastatin is eroded in 
lumpang until it becomes powder, then added $0.5 \% \mathrm{Na}$ CMC suspension and then put into lumpang and added suspension $\mathrm{Na} \mathrm{CMC} 0.5 \%$ little by little while being eroded until homogeneous and then put into pumpkin of course $10 \mathrm{~mL}$. The volume is sufficient with a $0.5 \% \mathrm{Na}$ CMC suspension up to the mark line (Mutia and Chiuman, 2019). Simvastatin suspension, as much as $10 \mathrm{mg}$ of simvastatin is eroded in lumpang until it becomes powder, then added $0.5 \% \mathrm{Na}$ CMC suspension and then put into the pumpkin of course $25 \mathrm{~mL}$. Volume is sufficient with a $0.5 \% \mathrm{Na}$ CMC suspension up to the mark line (Fouad and Jresat, 2013; Aldahmash and El-Nagar, 2016). Induction of Dyslipidemia in Animals Try, the induction process is done by giving a high-fat diet to the animal try for 14 days. A high-fat diet is provided with a high-fat feed suspension with a dose of $15 \mathrm{gr} / \mathrm{kgBB}$ for animal fat suspension and $10 \mathrm{gr} / \mathrm{kgBB}$ for poultry egg yolk suspension (Harsa, 2014; Untari and Pramukantoro, 2020).

\subsection{Test Animal Testing}

Dosage of ethanol extract mangosteen fruit skin and simvastatin as standard group, determined based on previous studies (Olayinka et al., 2014; Batubara, Sabri and Tanjung, 2017; Worotikan, Tuju and Kawuwung, 2017; Abarikwu et al., 2020). The treatment experienced by each of the mice in the group is as follows:

Table 2. Overview of the Treatment of Each Group

\begin{tabular}{|c|c|c|}
\hline No & Test Group & Treatment \\
\hline 1. & rmal & $\begin{array}{l}\text { Test animals are not given certain treatment and are only fed } \\
\text { and drank on an ad libitium basis. }\end{array}$ \\
\hline 2. & Control & $\begin{array}{l}\text { Test animals were given } 1 \mathrm{ml} \text { of uspense } \mathrm{Na} \text { CMC } 0.5 \% \text { once a } \\
\text { day for } 14 \text { days. Food and drink are given ad libitum. }\end{array}$ \\
\hline 3. & $\begin{array}{c}\text { Standard } \\
(25 \mathrm{mg} / \mathrm{kgBB})\end{array}$ & $\begin{array}{l}\text { Test animals were given uspense oral simvastatin } 5 \mathrm{ml} / \mathrm{kgBB} \\
\text { once a day for } 14 \text { days. Food and drink are given ad libitum. }\end{array}$ \\
\hline 4. & $\begin{array}{l}\text { Mangosteen Peel Ethanol } \\
\text { Extract - I (300 mg/ kgBB) }\end{array}$ & $\begin{array}{l}\text { Test animals were given mangosteen peel ethanol extract doses } \\
\text { of } 2.5 \mathrm{ml} / \mathrm{kgBB} \text { once a day for } 14 \text { days. Food and drink are } \\
\text { given ad libitum. }\end{array}$ \\
\hline 5. & $\begin{array}{l}\text { Mangosteen Peel Ethanol } \\
\text { Extract - II (600 mg/kgBB) }\end{array}$ & $\begin{array}{l}\text { Test animals were given a } 5 \mathrm{ml} / \mathrm{kgBB} \text { dose of mangosteen peel } \\
\text { ethanol extract once a day for } 14 \text { days. Food and drink are given } \\
\text { ad libitum. }\end{array}$ \\
\hline 6. & $\begin{array}{l}\text { Mangosteen Peel Ethanol } \\
\text { Extract }- \text { III (1200 } \\
\mathrm{mg} / \mathrm{kgBB})\end{array}$ & $\begin{array}{l}\text { Test animals were given a } 10 \mathrm{ml} / \mathrm{kgBB} \text { dose of mangosteen peel } \\
\text { ethanol extract once a day for } 14 \text { days. Food and drink are given } \\
\text { ad libitum. }\end{array}$ \\
\hline
\end{tabular}

\subsection{Data Analysis}

Analyze Anova's One-Way Test data if the data is normally distributed with advanced tests in the form of Post Hoc Tukey HSD tests to see real differences between treatments. However, as an alternative test if the distributed data is not normal, the Kruskall-wallis test is used as an alternative test. 


\section{Discussion}

\subsection{Results}

\section{a. Characteristics of Extract}

After extraction by maceration method against mangosteen peel samples found the following extract characteristics:

Table 3. Characteristics of Ethanol Extract Mangosteen Peel (Garcinia mangostana L.)

\begin{tabular}{ll}
\hline Characteristic & Value \\
\hline Weight of Fresh Simplisia (gr) & $500 \mathrm{gr}$ \\
Dry Simplisia Powder Weight (gr) & $212 \mathrm{gr}$ \\
Solvent Volume (ml) & $2120 \mathrm{ml}$ \\
Weight extract (gr) & $15,55 \mathrm{gr}$ \\
Yield $(\%)$ & $7.33 \%$ \\
\hline
\end{tabular}

From the table data above it can be seen that from 500 grams of mangosteen peel samples were found to be extracts amounting to 15.55 grams. Thus, the amount of yield obtained from mangosteen peel ethanol extract is $7.33 \%$. Phytochemical screening results of phytochemical screening in samples of mangosteen peel ethanol extract can be seen in the following table.

Table 4. Phytochemical Screening Results of Mangosteen Peel Ethanol Extract

\begin{tabular}{|c|c|c|}
\hline Fitokimia & Reactor & Result \\
\hline \multirow[t]{4}{*}{ Alkaloid } & Bouchardart & + \\
\hline & Mayer & + \\
\hline & Dragondroff & - \\
\hline & Wagner & + \\
\hline Saponin & Aquadest + Alcohol 96\% & - \\
\hline \multirow[t]{4}{*}{ Flavonoid } & $\mathrm{FeCl} 35 \%$ & + \\
\hline & $\mathrm{Mg}_{(\mathrm{s})}+\mathrm{HCl}_{(\mathrm{p})}$ & - \\
\hline & $\mathrm{NaOH} 10 \%$ & - \\
\hline & $\mathrm{H}_{2} \mathrm{SO}_{4}(\mathrm{p})$ & - \\
\hline Tanin & $\mathrm{FeCl}_{3} 1 \%$ & + \\
\hline \multirow[t]{2}{*}{ Steroid dan Terpenoid } & Salkowsky & - \\
\hline & Liberman Bouchard & + \\
\hline
\end{tabular}

From the table data above it can be seen that mangosteen peel ethanol extract contains several phytochemical compounds including Alkaloids, Saponins, Flavonoids, Tannins, as well as Steroids and Terpenoids. 


\section{b. Evaluation of Anti-Dyslipidemia Effects}

All parameters evaluated in the study included body weight, total cholesterol, lipid profile, SGOT levels, and SGPT analyzed the normality of the data using the Shapiro-Wilk test. The results of the normality analysis can be seen in the table below.

Table 5. Data Normality Test Results with Shapiro-Wilk Test of All Research Parameters

\begin{tabular}{|c|c|c|c|}
\hline \multicolumn{2}{|l|}{ Parameter } & P-Value & Data Distribution \\
\hline \multicolumn{2}{|l|}{ Weight } & 0.396 & Normal \\
\hline \multicolumn{2}{|c|}{ Total Cholesterol Before Induction } & $<0.05$ & Abnormal \\
\hline \multicolumn{2}{|c|}{ Total Cholesterol After Induction } & $<0.05$ & Abnormal \\
\hline \multirow{4}{*}{$\begin{array}{l}\text { Profil Lipid After } \\
\text { treatment }\end{array}$} & Total Cholesterol & 0.489 & Normal \\
\hline & Trigliserida & 0.003 & Abnormal \\
\hline & levels HDL & $<0.05$ & Abnormal \\
\hline & levels LDL & 0.132 & Normal \\
\hline \multicolumn{2}{|l|}{ levels SGOT } & $<0.05$ & Abnormal \\
\hline \multicolumn{2}{|l|}{ levels SGPT } & 0.052 & Normal \\
\hline
\end{tabular}

From the table data above it can be seen that the data on weight, total cholesterol and LDL levels of the lipid profile after treatment, and SGPT levels have a normal data distribution, while other parameters include: total cholesterol before and after induction, triglyceride levels, HDL levels, and abnormally distributed SGOT levels. Based on the distribution of these data, the data with normal data distribution is analyzed with parametric satistics while abnormal data is analyzed with non-parametric statistics.

\section{c. Rat Weight}

To uniformize the weight of the mice used in the study, all the mice used in the study weighed their weight first. Then a comparison was made on the entire weight of the mice. The results of the comparison can be seen in the following table:

Table 6. Comparison of Early Weight of Mice in the Entire Treatment Group

\begin{tabular}{lllc}
\hline Treatment Group & Weight (gram) & P-Value \\
\cline { 2 - 3 } & \multicolumn{2}{c}{ Mean } & \\
\hline Normal & 245.00 & 37.79 & \\
Standard & 239.75 & 15.61 & \\
Control & 248.50 & 23.67 & \multirow{2}{*}{0.987} \\
Mangosteen Peel Ethanol Extract - I & 248.50 & 25.59 & \\
Mangosteen Peel Ethanol Extract -II & 239.75 & 23.62 & \\
Mangosteen Peel Ethanol Extract -III & 240.75 & 13.89 &
\end{tabular}

From the table data above can be seen the value of $\mathrm{P}>0.05$ (Value $\mathrm{P}=0.987$ ) which means there is no significant difference to the initial weight of the mice used in this study. The 
weight span of the mice used in the study ranged from 212-300grams evenly spread across each treatment group.

\section{d. Total Cholesterol}

In evaluating the anti-dislipidemia effects of mangosteen peel, a high-fat diet was administered to the control group, standard, mangosteen peel extracts I, II, and III. Before and after the high-fat diet, total cholesterol in all mice was measured and all total cholesterol data was analyzed with non-parametric statistics. The results of the analysis can be seen in the following table.

Table 7. Comparison of Total Cholesterol before and after High-Fat Diet in All Treatment Groups

\begin{tabular}{lll}
\hline Treatment Group & \multicolumn{2}{l}{ Total Cholesterol (mg/dL) } \\
\cline { 2 - 3 } & Before induction & After induction \\
\hline Normal & $116.50(110-117)$ & $118.50(112-121)^{\mathrm{b}}$ \\
Standard & $112.00(100-115)$ & $211.00(209-213)^{\mathrm{a}}$ \\
Control & $115.50(110-118)$ & $210.50(210-212)^{\mathrm{b}}$ \\
Mangosteen Peel Ethanol Extract - I & $115.50(110-117)$ & $210.50(208-214)^{\mathrm{b}}$ \\
Mangosteen Peel Ethanol Extract -II & $110.50(100-115)$ & $210.50(209-212)^{\mathrm{b}}$ \\
Mangosteen Peel Ethanol Extract -III & $117.50(117-120)$ & $209.00(208-213)^{\mathrm{b}}$ \\
\hline P-Value & $\mathbf{0 . 8 8 6}$ & $\mathbf{0 . 0 2 9}$ \\
\hline
\end{tabular}

The data is displayed as Median (Range). The value of P is derived from the Kruskal-Wallis analysis; Different superscripts in the same column show significant differences.

From the table data above it can be seen that before being given a high-fat diet, the total cholesterol of mice before the administration of a high-fat diet in the entire treatment group showed no significant difference (Value $\mathrm{P}=0.866$ ). This showed that the total cholesterol data of mice before being given a high-fat diet was uniform. However, total cholesterol in the entire group of mice after a high-fat diet showed a different distribution, with only the control group, standard, ethanol extract from mangosteen fruit skin I, II, and III showing a uniform total cholesterol.

\section{e. Lipid Profile}

At the end of the study, all of the mice were terminated for blood and analyzed lipid profile and liver function (SGOT/SGPT). Comparison of plipid profiles across the mouse treatment group can be seen in the table below.

Table 8. Comparison of Lipid Profiles in the Entire Group of Rat Treatments

\begin{tabular}{lllll}
\hline \multirow{2}{*}{ Treatment Group } & \multicolumn{3}{c}{ Lipid Profile } \\
\cline { 2 - 5 } & \multicolumn{1}{c}{ Total Kolestrol* } & \multicolumn{1}{c}{ Trigliserida** } & LDL* & HDL** \\
\hline Normal & $134.50 \pm 2.40 \mathrm{a}$ & 98.50 & $52.25 \pm 1.71 \mathrm{a}$ & $62.50(61-$ \\
& & $(97-100) \mathrm{a}$ & $64) \mathrm{a}$ \\
Standard & $144.50 \pm 0.58 \mathrm{~b}$ & 102.50 & $62.50 \pm 1.29 \mathrm{~b}$ & $61.50(60-$ \\
& & $(101-105) \mathrm{b}$ & & $63) \mathrm{a}$
\end{tabular}




\begin{tabular}{|c|c|c|c|c|}
\hline Control & $179.25 \pm 6.02 c$ & $\begin{array}{l}166.50 \\
(162-179) c\end{array}$ & $106.00 \pm 3.65 c$ & $\begin{array}{l}29.50(38- \\
43) b\end{array}$ \\
\hline $\begin{array}{l}\text { Mangosteen Peel Ethanol Extract - } \\
\text { I }\end{array}$ & $168.25 \pm 1.50 \mathrm{~d}$ & $\begin{array}{l}133.50 \\
(133-135) \mathrm{d}\end{array}$ & $83.75 \pm 2.62 \mathrm{~d}$ & $\begin{array}{l}57.50(56- \\
59) \mathrm{b}\end{array}$ \\
\hline $\begin{array}{l}\text { Mangosteen Peel Ethanol Extract - } \\
\text { II }\end{array}$ & $163.25 \pm 2.22 \mathrm{e}$ & $\begin{array}{l}120.50 \\
(119-122) \mathrm{e}\end{array}$ & $77.50 \pm 1.29 \mathrm{e}$ & $\begin{array}{l}61.50(61- \\
63) \mathrm{a}\end{array}$ \\
\hline $\begin{array}{l}\text { Mangosteen Peel Ethanol Extract - } \\
\text { III }\end{array}$ & $151.75 \pm 0.96 \mathrm{e}$ & $\begin{array}{l}110.00 \\
(109-112) f\end{array}$ & $68.50 \pm 1.29 f$ & $\begin{array}{l}61.00(60- \\
63) \mathrm{a}\end{array}$ \\
\hline P-Value & $<0.05$ & 0.029 & $<0.05$ & 0.029 \\
\hline
\end{tabular}

From the table data above it can be seen that all lipid profile data in the entire treatment group showed significant differences.

a. Total cholesterol in the entire treatment group of mice showed a significant difference, this can be seen from the value of $\mathrm{P}<0.05$. The average total cholesterol was lowest in the normal group of $134.50 \pm 2.40 \mathrm{mg} / \mathrm{dL}$, followed by the standard group of $144.50 \pm$ $0.58 \mathrm{mg} / \mathrm{dL}$, the mangosteen peel ethanol extract group I, II, III, and the group with the highest total cholesterol was the control group of $179.25 \pm 6.02 \mathrm{mg} / \mathrm{dL}$.

b. b. Triglyceride levels in the entire treatment group also showed significant differences, this can be seen from the value of $\mathrm{P}<0.05$ (Value $\mathrm{P}=0.029$ ). The lowest trend of triglyceride levels was found in the normal group of $98.50 \mathrm{mg} / \mathrm{dL}$, followed by the standard group of $102.50 \mathrm{mg} / \mathrm{dL}$, the ethanol extract group mangosteen fruit skin I, II, III, and the group with the highest triglyceride levels was the control group of $166.50 \mathrm{mg}$ / dL.

c. C. LDL levels also showed significant differences across the treatment group, this can be seen from the value of $\mathrm{P}<0.05$. The lowest average LDL levels were found in the normal group of $52.25 \pm 1.71 \mathrm{mg} / \mathrm{dL}$, followed by the standard group of $62.50 \pm 1.29 \mathrm{mg} / \mathrm{dL}$, the ethanol extract group mangosteen fruit skin I, II, III, and the group with the highest LDL levels was the control group of $106.00 \pm 3.65 \mathrm{mg} / \mathrm{dL}$.

d. d. HDL levels also showed significant differences across the treatment group, this can be seen from the value of $\mathrm{P}<0.05$ (Value $\mathrm{P}=0.029$ ). The highest hdl levels were found in the normal group of $62.50 \mathrm{mg} / \mathrm{dL}$, followed by the standard group of $61.50 \mathrm{mg} / \mathrm{dL}$, the ethanol extract group mangosteen fruit skin I, II, III, and the group with the lowest HDL levels was the control group of $29.50 \mathrm{mg} / \mathrm{dL}$.

\section{f. Liver Function}

Another parameter that was also assessed in the entire group of mice at the end of the study was liver function, namely: SGOT and SGPT levels. Comparison of SGOT and SGPT levels in the entire group of rat treatment can be seen in the table below.

Table 9. Comparison of SGOT and SGPT Levels in All Treatment Groups

\begin{tabular}{lll}
\hline Treatment Group & Levels SGOT (U/L) & Levels SGPT (U/L) \\
\hline Normal & $28.50(27-30)^{\mathrm{a}}$ & $47.25 \pm 1.50^{\mathrm{a}}$ \\
Standard & $110.50(108-112)^{\mathrm{b}}$ & $171.50 \pm 1.29^{\mathrm{b}}$ \\
Control & $168.50(162-170)^{\mathrm{c}}$ & $97.25 \pm 1.50^{\mathrm{c}}$ \\
Mangosteen Peel Ethanol Extract - I & $118.50(118-120)^{\mathrm{d}}$ & $100.75 \pm 3.59^{\mathrm{d}}$ \\
\hline
\end{tabular}




\begin{tabular}{|c|c|c|}
\hline Mangosteen Peel Ethanol Extract -II & $122.50(121-124)^{e}$ & $115.50 \pm 4.51^{\mathrm{e}}$ \\
\hline Mangosteen Peel Ethanol Extract -III & $130.50(129-132)^{\mathrm{f}}$ & $142.50 \pm 2.08^{b}$ \\
\hline P-Value & 0.029 & $<0.05$ \\
\hline
\end{tabular}

From the table data above, it was seen that SGOT and SGPT levels in the entire rat treatment group showed significant differences, this is seen from the value of $\mathrm{P}<0.05$. The tendency of the highest SGOT levels was found in the control group which was $168.50 \mathrm{U} / \mathrm{L}$ and the lowest normal group was $28.50 \mathrm{U} / \mathrm{L}$. Meanwhile, a similar picture was found in the SGPT level, the group with the highest SGPT level was found in the control group which was $171.50 \mathrm{U} / \mathrm{L}$ and the low was added to the normal group of $47.25 \mathrm{U} / \mathrm{L}$.

\subsection{Discussion}

The results of this study showed that mangosteen peel ethanol extract showed significant improvements in lipid profile at the end of the study. Mangosteen peel ethanol extract at the highest dose showed the most optimal improvement in lipid profile. This can be seen from the decrease in total cholesterol levels, triglycerides, and LDL as well as an increase in HDL levels of the mangosteen skin ethanol group II and III. However, this improvement in lipid profile in the rat group of Mangosteen-III Fruit Peel Ethanol Extract did not exceed the improvement shown in the standard group.

The anti-dislipidemia effect possessed by ethanol extract mangosteen peel can be related to the content of various phytochemicals in the mangosteen fruit. Several studies have shown the potential of phytochemicals as anti-dyslipidemia. Polyphenol content can cause down-regulation of pro-inflammatory cells signal modulation such as nuclear factor- $x \mathrm{~B}$, activated protein-1, and mitogen-activated protein kinase through the inhibition of the arachidonic acid cascade and eicosanoids derivates. Another mechanism that allows the antidyslipidemia effects of polyphenol compounds is the regulation of intestinal microbiota. Polyphenol compounds in the usu will interact with the gut microbiota thus increasing various beneficial metabolite products such as short-chain free fatty acids, in addition to usu microbes such as Akkermansia municiphilia sp. Restore inflammatory conditions in the intestines, improve intestinal permeability, and insulin sensitivity. Furthermore, this improvement to the gut microbiota protects the gut-liver axis thereby lowering lipid profiles in the body (Sun, Wang and Qin, 2018; Feldman et al., 2021).

Other studies discussing the anti-dyslipidemia effects of mangosteen peel ethanol are still limited. But, Dharmayanti (2018), who conducted a study on the Effects of Mangosteen Peel Ethanol Extract (Garcinia Mangostana.L) on LDL Levels in NIDDM Type Mice, reported that mangosteen peel extract provided an LDL reduction effect in NIDDM type mice (Dharmayanti, 2018). The diagnosis of dyslipidemia can be established based on increased ldl levels in the plasma. Xanthones found in the skin of mangosteen fruit are antioxidant, antidiabetic, anticancer, antiimflammatory, hepatoprotective, immunomodulation, aromatase inhibitor, antibacterial, also other functional, mangosteen fruit skin (Garcinia mangostana. L) is beneficial for health because it contains anthocyanins, tannins, phenol/polyphenol compounds, epicatekins, and xanthone (Supiyanti, Wulansari and Kusmita, 2010).

In addition, mangosteen peel ethanol extract also significantly lowered SGOT and SGPT levels compared to the control group. This decrease in SGOT and SGPT levels is 
associated with improvement of Non-Alcoholic Fatty Liver Disease (NAFLD). Several studies have shown that NAFLD is a risk factor for arteriosclerosis. This is because NAFLD causes dysfunction of the endothelial blood vessels. Thong and Quynh (2021) report that both SGOT and SGPT correlate with the occurrence of NAFLD, but the use of SGOT and SGPT separately can indicate errors in confirming mild NAFLD. In the case of severe NAFLD, SGOT will increase slightly and in milder cases, SGOT levels can be found in normal amounts. Therefore, the use of SGOT and SGPT unilaterally may allow errors in confirming mild degree NAFLD (Thong and Quynh, 2021).

In this study, SGOT and SGPT levels in the group of mice that received mangosteen peel ethanol extract were lower than the levels of SGOT and SGPT from the control group. This suggests that mangosteen peel ethanol extract may protect liver tissue from NAFLD compared to the group that did not get mangosteen peel ethanol extract. However, the possibility of mild degree NAFLD in the group of mice that get mangosteen skin ethanol extract cannot be removed.

\section{Conclusion}

The conclusion of this study, that ethanol extract mangosteen fruit peel significantly decreased total cholesterol, triglyceride levels, LDL levels, SGOT levels compared to the control group. Mangosteen peel ethanol extract can significantly increase HDL levels compared to the control group.

\section{References}

Abarikwu, S. O. et al. (2020) 'Evaluation of the protective effects of quercetin and gallic acid against oxidative toxicity in rat's kidney and HEK-293 cells', Toxicology Reports, 7(February), pp. 955-962. doi: 10.1016/j.toxrep.2020.07.015.

Aldahmash, B. A. and El-Nagar, D. M. (2016) 'Antioxidant Effects of Captopril against Lead Acetate-Induced Hepatic and Splenic Tissue Toxicity in Swiss Albino Mice', Saudi Journal of Biological Sciences, 23(6), pp. 667-673. doi: 10.1016/j.sjbs.2016.05.005.

Anneke, R. and Sulistiyaningsih (2018) 'Review: Terapi Herbal sebagai Alternatif Pengobatan Dislipidemia’, Farmaka, 16, pp. 213-221.

Arsana, P. M. et al. (2015) Panduan Pengelolaan Dislipidemia di Indonesia. Jakarta: PB Perkeni.

Badan Penelitian Dan Pengembangan Kesehatan Kementerian Kesehatan RI (2013) Riset Kesehatan Dasar 2013, Kementrian Kesehatan Republik Indonesia. doi: 1 Desember 2013.

Bahri, S., Pasaribu, F. and Sitorus, P. (2012) 'Uji Ekstrak Etanol Kulit Buah Manggis (Garcinia Mangostana ,L) Terhadap Penurunan Kadar Glukosa Darah', Journal of Pharmaceutics and Pharmacology, 1(1), pp. 1-8.

Batubara, M. S., Sabri, E. and Tanjung, M. (2017) 'Pengaruh Pemberian Ekstrak Etanol Daun Andaliman (Zanthoxylum acanthopodium DC.) terhadap Gambaran Morfologi Ovarium Mencit (Mus musculus L.) Strain DDW', Klorofil, 1(1), pp. 5-10.

Dalimartha, S. and Adrian, F. (2013) Ramuan Herbal Tumpas Penyakit. Jakarta: Penebar Swadaya.

Dharmayanti, L. (2018) 'Efek Ekstrak Etanol Kulit Buah Manggis (Garcinia Mangostana. L) terhadap Kadar LDL pada Tikus Tipe NIDDM', 1, pp. 255-260.

Erwinanto et al. (2013) Pedoman Tatalaksana Dislipidemia. Jakarta: Perhimpunan Dokter Spesialis Kardiovaskular Indonesia. doi: 10.1136/bcr.09.2008.0970. 
Feldman, F. et al. (2021) 'Efficacy of polyphenols in the management of dyslipidemia: A focus on clinical studies', Nutrients, 13(2), pp. 1-42. doi: 10.3390/nu13020672.

Fouad, A. A. and Jresat, I. (2013) 'Captopril and telmisartan treatments attenuate cadmiuminduced testicular toxicity in rats', Fundamental and Clinical Pharmacology, 27(2), pp. 152-160. doi: 10.1111/j.1472-8206.2011.00974.x.

Go, A. S. et al. (2014) 'Heart Disease and Stroke Statistics - 2014 Update: A report from the American Heart Association', Circulation, 2014(129), pp. e28-e292. doi: 10.1161/01.cir.0000441139.02102.80.

Harsa, I. M. S. (2014) 'Efek Pemberian Diet Tinggi Lemak Terhadap Profil Lemak Darah Tikus Putih (Rattus norvegicus)', Universitas Wijaya Kusuma, 31(1), pp. 21-28.

Jang, M. H. et al. (2008) 'Inhibition of cholinesterase and amyloid-\&bgr; aggregation by resveratrol oligomers from Vitis amurensis', Phytotherapy Research, 22(4), pp. 544549. doi: $10.1002 /$ ptr.

Kosasih, E. et al. (2019) 'Hepatoprotective Effect of Citrus Sinensis Peel Extract Against Isoniazid and Rifampicin-induced Liver Injury in Wistar Rats', Majalah Obat Tradisional, 24(3), pp. 197-203. doi: 10.22146/mot.45762.

Lin, C. F. et al. (2018) 'Epidemiology of Dyslipidemia in the Asia Pacific Region', International Journal of Gerontology, 12(1), pp. 2-6. doi: 10.1016/j.ijge.2018.02.010.

Mutia, M. S. and Chiuman, L. (2019) 'Hepatoprotective Effect of Citrus sinensis ( L .) Osbeck Ethanol Extract in Paracetamol-Induced Rats Efek Hepatoprotektif Ekstrak Etanol Citrus sinensis L. Osbeck pada Tikus yang Diinduksi Parasetamol', Majalah Kedokteran Bandung, 51(4), pp. 189-193.

Olayinka, E. T. et al. (2014) 'Protective effect of quercetin on melphalan-induced oxidative stress and impaired renal and hepatic functions in rat', Chemotherapy Research and Practice, 2014. doi: 10.1155/2014/936526.

Ovalle-Magallanes, B., Eugenio-Pérez, D. and Pedraza-Chaverri, J. (2017) 'Medicinal properties of mangosteen (Garcinia mangostana L.): A comprehensive update', Food and Chemical Toxicology, 109, pp. 102-122. doi: 10.1016/j.fct.2017.08.021.

Parmita, R. I., In, M. and Armyanti, I. (2017) 'Uji Efek Antiinflamasi Kombinasi Astaxanthin dan Ekstrak Kulit Manggis (Garcinia mangostana Linn) pada Tikus Putih Galur Wistar Abstrak PENDAHULUAN Inflamasi merupakan suatu respon protektif yang ditujukan drug / NSAID) namun memiliki efek samping yang', 3, pp. 689-696.

Purva, A., Sharma, K. and Khan, M. S. (2020) 'A Review on Dyslipidemia: Types, Risk Factors and Management', Asian Journal of Pharmaceutical Research and Development, 8(2), pp. 96-98. doi: 10.22270/ajprd.v8i2.682.

Puspitaningrum, I., Kusmita, L. and Setyani, W. (2014) 'Efek Analgetik Antipiretik Ekstrak Etanol Kulit Buah Manggis (Garcinia Mangostana L.) pada Tikus Putih Jantan Galur Wistar', e-Publikasi Ilmiah Fakultas Farmasi Unwahas Semarang, 11(1), pp. 18-24. Available

at: http://www.publikasiilmiah.unwahas.ac.id/index.php/ilmuFarmasidanklinik/article/vi ew/1284.

Putra SR (2012) Rahasia-Rahasia Keajaiban Kulit Buah Manggis. Cetakan 1. Jogjakarta: Diva Press.

Saragih, A. D. (2020) 'Terapi Dislipidemia untuk Mencegah Resiko Penyakit Jantung Koroner', Indonesian Journal of Nursing and Health Sciences Volume, 1(1), pp. 1524.

Sun, Y. E., Wang, W. and Qin, J. (2018) 'Anti-hyperlipidemia of garlic by reducing the level of total cholesterol and low-density lipoprotein', Medicine (United States), 97(18), pp. 18. doi: 10.1097/MD.0000000000010255. 
Supiyanti, W., Wulansari, E. D. and Kusmita, L. (2010) 'Uji Aktivitas Antioksidan dan Penentuan Kandungan Antosianin Total Kulit Buah Manggis (Garcinia mangostana L)', Majalah Obat Tradisional, 15(2), pp. 64-70.

Taqwin, R. M. (2014) 'Uji efek ekstrak etanol 70\% daging buah asam jawa (Tamarindus indica L) Terhadap Penurunan Kadar Kolesterol Total dan Trigliserida pada Tikus Putih Jantan (Rattus norvegicus) Galur Wistar dengan Dislipidemia', Naskah Publikasi.

Thong, V. D. and Quynh, B. T. H. (2021) 'Correlation of serum transaminase levels with liver fibrosis assessed by transient elastography in vietnamese patients with nonalcoholic fatty liver disease', International Journal of General Medicine, 14, pp. 1349-1355. doi: 10.2147/IJGM.S309311.

Untari, M. K. and Pramukantoro, G. E. (2020) 'Aktivitas Antihiperkolesterolemia Ekstrak Etanol Daun Stevia Rebaudiana Bertoni Pada Tikus Putih Jantan', Journal Syifa Sciences and Clinical Research, 2(1), pp. 11-20. doi: 10.37311/jsscr.v2i1.2700.

Widowati, W. et al. (2016) 'Antioxidant and Anti Aging Assays of Oryza sativa Extracts, Vanillin and Coumaric Acid', Journal of Natural Remedies, 16(3), pp. 88-99. doi: 10.18311/jnr/2016/7220.

Widowati, W. et al. (2017) 'Antioxidant and antiaging assays of Hibiscus sabdariffa extract and its compounds', Natural Product Sciences, 23(3), pp. 192-200. doi: 10.20307/nps.2017.23.3.192.

Widowati, W. et al. (2018) 'Antioxidant and antiaging activities of Jasminum sambac extract, and its compounds', Journal of Reports in Pharmaceutical Sciences, 7(3), pp. 270-285.

Worotikan, R. V., Tuju, E. A. and Kawuwung, F. (2017) 'Analisa Efektivitas Antidiabetes Ekstrak Etanol Buah Andaliman (Zanthoxylum acanthopodium DC) pada Histopatologi Ginjal Tikus Putih (Rattus norvergicus) yang Diinduksi Alloksan', Jurnal Sains Matematika \& Edukasi, 5(1), pp. 29--37. 